Ambiente \& Água - An Interdisciplinary Journal of Applied Science
ISSN 1980-993X - doi:10.4136/1980-993X
www.ambi-agua.net
E-mail: ambi.agua@gmail.com

\title{
Analytical solution for the stationary model of pollutant propagation in an aquatic medium
}

\author{
ARTICLES doi:10.4136/ambi-agua.2298
}

Received: 13 Jul. 2018; Accepted: 11 Jan. 2019

\author{
Cíntia Ourique Monticelli ${ }^{*}$; ; Jorge Rodolfo Zabadal ${ }^{2}$; \\ Daniela Muller Quevedo ${ }^{1}$; ; Carlos Augusto Nascimento ${ }^{1}$ id \\ ${ }^{1}$ Universidade FEEVALE (FEEVALE), Novo Hamburgo, RS, Brasil \\ Instituto de Ciências Exatas e Tecnológicas (ICET). E-mail: cintiam@feevale.br, \\ danielamq@feevale.br, nascimento@feevale.br \\ ${ }^{2}$ Universidade Federal do Rio Grande do Sul (UFRGS), Tramandaí, RS, Brasil \\ Departamento Interdisciplinar. E-mail: jorge.zabadal@ufrgs.br \\ *Corresponding author
}

\begin{abstract}
This work presents a new analytical approach for solving pollutant dispersion problems along irregular-shaped water bodies. In this approach, the advection-diffusion equation is expressed in terms of orthogonal curvilinear coordinates, defined by the velocity potential and the corresponding stream function for inviscid flows. The boundary condition rewritten in terms of these new coordinates is reduced to a classical third kind one, i.e., the derivative of the concentration distribution with respect to the stream function is proportional to the numerical value of the local pollutant concentration. The solution obtained from the proposed formulation was employed to simulate pollutant dispersion (thermotolerant coliforms) along the Pampa Creek, a tributary of the Sinos River at the outskirts of Novo Hamburgo city, South Region of Brazil. The results obtained reproduce the qualitative behavior of the expected concentration distribution.
\end{abstract}

Keywords: advection-diffusion equation, analytical solutions, mass transport, orthogonal curvilinear coordinates system, pollutant dispersion.

\section{Solução analítica do modelo estacionário de propagação de poluentes em meio aquático}

\section{RESUMO}

Este trabalho apresenta uma nova abordagem analítica para a solução de problemas de dispersão de poluentes ao longo de corpos hídricos com contornos irregulares. Nesta abordagem, a equação advectivo-difusiva é expressa em termos de coordenadas curvilíneas ortogonais que são definidas pelo potencial de velocidade e pela função de corrente correspondente para fluídos invíscivos. A condição de contorno reescrita em termos destas novas coordenadas é reduzida a uma de terceira espécie clássica, isto é, a derivada da distribuição de concentração em relação à função de corrente é proporcional ao valor numérico da concentração de poluente local. A solução obtida a partir da formulação proposta foi empregada para simular dispersão de poluentes (coliformes termotolerantes) ao longo do Arroio Pampa, afluente do rio dos Sinos, na periferia de Novo Hamburgo, cidade do sul do Brazil. Os 
resultados obtidos reproduzem o comportamento qualitativo da distribuição de concentração esperada.

Palavras-chave: dispersão de poluentes, equação advectivo-difusiva, sistema de coordenadas curvilíneas ortogonais, soluções analíticas, transporte mássico.

\section{INTRODUCTION}

The conservation of surface water quality is of great importance for society, since this water is collected in order to supply public distribution systems. However, due to their power of dilution and self-purification, several rivers also serve as the final destination of sanitary sewage. Hence, the technical tools to aid in the planning, monitoring and management of water resources, among which mathematical modeling stands out as a fundamental instrument, are very important. Mathematical models allow the generation of properly organized data, spatially and temporally integrating dispersed data, as well as promoting a better understanding of the dynamics of the processes and a prediction of future conditions of the system regarding relevant parameters.

Rivers are the main source of water for human consumption. Thus, controlling the water quality of the rivers is very important because water is directly related to human health (Qishlaqi et al., 2017). In environmental impact studies of sewage transport network projects, part of the data to be produced is the determination of a safe distance from the vicinal area or points of raw water collection for water treatment plants, where effluents can be discharged through an emissary so that the dispersion plume does not reach these areas. Surely, one can also estimate the contamination level that would be produced if the pollutant inevitably reached the regions of interest.

To obtain reliable results regarding the distance of the sewage outfall in relation to the source and to the point of water collection, and thus minimize the total costs of an enterprise, it is necessary to carry out several computational simulations. These simulations would be able to predict the approximate spatial distribution of pollutant concentrations considering a large quantity of scenarios by using mathematical models for mass transport. However, the time required by computational programs capable of implementing such models can become a critical point for certain applications that require a high level of detail, since the large number of mathematical calculations in a commonly used numerical model (Rosman, 2001), (Gomes et al., 2018) causes delays in the generation of the results.

The governing equation of pollutant transmission in rivers is the advection diffusion equation (ADE). This is a partial equation that is very important in environmental engineering, and several hydraulic phenomena such pollution transmission, suspended sediment transport modeling, etc. are involved (Parsaie and Haghiabi, 2017). The ADE includes two differential parts, advection and diffusion; the advection part characterizes the velocity's contribution in the pollutant transmission, and the diffusion or dispersion part characterizes the molecular transmission from highest concentration region to lowest concentration region. In addition to the differential terms present in ADE, there are the physical parameters which will be described throughout this work.

Three possible solutions could be proposed to solve the differential equation that describe the problem in question: the numerical, analytical and hybrid methods. Numerical methods, usually employed by the scientific community, often provide sufficiently realistic results for particle transport problems (Jobim, 2012). In the application of numerical solutions to computational fluid dynamics, either by applying the finite difference, finite element or finite volume methods and artificial neural network - ANN (Parsaie and Haghiabi, 2017), it is common to have to discretize the domain into a mesh with thousands or even millions of points. 
This may produce algebraic systems of a very high order (Fernandez, 2007); thus, in most cases, the numerical solutions demand a high computational effort. Consequently, they require a high processing time, which may make it impossible in some cases to generate a sufficient number of scenarios in a timely manner.

In order to avoid these problems, the use of analytical solutions is more advantageous. As they are expressed in closed form, it is possible to write small source codes that are executed in a shorter processing time, which is due to the decrease in the number of operations to be performed and, consequently, in the memory required for all the necessary routines. The advection-diffusion equation, which describes the transport of particles, has several proposed analytical solutions, such as the integral transform method (Mikhailov and Ozisik, 1984), the generalized integral transform method (Cotta, 1993), the change of variables combined with the integral transform method (Guerrero et al., 2009), using the Green's function (Sanskrityayn and Kumar, 2016), among others. However, changes in the geometry of the domain are not considered, whereas this would be required in the problem of transporting particles in a water body.

This study presents a new analytical approach to solve the problem of pollutant dispersion in the aquatic environment, in which the advection-diffusion equation is expressed in terms of new orthogonal curvilinear coordinates, defined by the velocity potential and by the stream function. Such reformulation aims to standardize the boundary conditions to be prescribed, in addition to considerably increasing the size of the elements of the corresponding mesh. The use of this technique produces a closed solution for the propagation model of conservative or nonconservative pollutants and its implementation generates very compact symbolic codes and high computational performance.

In addition, the that way the physical parameters, present in the ADE, are obtained has fundamental importance. The determination of the longitudinal dispersion coefficients that properly describes the stream behavior is one of the main objectives of research works, like those of Paisaie et al. (2018) Haghiabi (2016; 2017), that use different techniques to obtain them. In the solution proposed by this study, the dispersion coefficients used are the ones obtained by Garcia in 2009 and the velocity coefficients obtained by Lersh et al. in 2013.

In order to prove the feasibility and validity of the proposed method, we present the results of a one-dimensional model for the simulation of dispersion of organic pollutants (thermotolerant coliforms) in a $7 \mathrm{~km}$-stretch of the Pampa Creek until its mouth in the Sinos River - located in an urban area of the city of Novo Hamburgo, Rio Grande do Sul, Brazil.

\section{MATERIAL AND METHODS}

\subsection{Equations Model}

In this study, in order to obtain an approximation for estimating the concentration of thermotolerant coliforms downstream from a point source, the flow was considered to be: homogeneous, isotropic, uniform, incompressible and irrotational. That is, respectively: absence of regions with "superconcentrations" or even actions of fields that interact with the substance of interest, absence of the characteristic that causes the molecule to migrate from one point to another that differ in each direction of pollutant propagation, and the pressure and turbulence temperature conditions are approximately the same at all points. The velocity field has divergent zero, i.e., there are no diffusive terms nor generation or decay. And finally, considering the irrotational flow to be the viscosity effects forming the hydrodynamic boundary layer on the banks of the river, they can be neglected and the fluid considered with viscosity equal to zero, which does not constitute vorticity.

Yet, many rivers and lakes can be reduced to a two-dimensional problem by behaving like water slides, since the depth is much smaller than the distance between the boundaries, so the 
dispersion would have enough time to homogenize the vertical concentration profile at the moment the plume has spread horizontally on a geographic scale. Consequently, the dispersion in the z-direction will be neglected.

With the changes and simplifications applied to the general equation of the particle balance (Cranck, 1975; Kambe, 2007) based on an Eulerian view of the process, and assuming that the kinetics of reactions could be represented by a first-order decay, the two-dimensional advection-diffusion equation for non-conservative pollutants is given as Equation 1:

$\frac{\partial C}{\partial t}+u \frac{\partial C}{\partial x}+v \frac{\partial C}{\partial y}=D\left(\frac{\partial^{2} C}{\partial x^{2}}+\frac{\partial^{2} C}{\partial y^{2}}\right)-k C$

In Equation 1, $C$ is the pollutant concentration, $x$ and $y$ are the directions of motion, $u$ and $v$ are the velocities of the water body in the directions $x$ and $y$ respectively, $D$ is the surface oscillation diffusion coefficient (Garcia et al., 2009) and $k$ is the coefficient of velocity.

When one intends to estimate the level of pollution caused by the discharge of sewage systems in different regions of a watercourse, whether for classification and framing according to current regulations or for the projection of bathing conditions, it is desirable to generate results that express the system in its steady state. Since the time scale in which the dispersion occurs is much higher than the characteristic period of the thermal and hydrodynamic fluctuations of the flow, the time evolution pattern of the diffusion, kinetic and velocity field coefficients present stationarity, that is, low amplitude stochastic oscillations around a fixed mean value. In this study, the coefficients of diffusion and velocity shall be considered constant, representing temporal arithmetic means independent of time.

Since the only transient effect on the concentration distribution to be considered is due to the effects of degradation kinetics, which is a phenomenon independent of mass transport, Equation 1 can be decoupled through the split process (Zabadal and Ribeiro, 2012):

In the kinetic Equation 2:

$\frac{\partial C}{\partial t}=-k C$

And in the transport Equation 3:

$u \frac{\partial C}{\partial x}+v \frac{\partial C}{\partial y}=D\left(\frac{\partial^{2} C}{\partial x^{2}}+\frac{\partial^{2} C}{\partial y^{2}}\right)$

\subsection{Analytical Solution}

With the target equation decoupled in a system of two equations, Equation 2 and Equation 3 , they can be solved in parallel.

\subsubsection{Solution of the kinetic equation for first-order decay}

The asymptotic behavior of the kinetic model for most pollutants is exponential, thus solving Equation 2 by separation of variables we obtain Equation 4:

$C(x, y, t)=f(x, y) e^{-k t}$

The function $f(x, y)$ is precisely the exact solution for the transport equation, Equation 3. Thus, substituting Equation 5 into Equation 3 restored the transport equation:

$\left(u \frac{\partial f}{\partial x}+v \frac{\partial f}{\partial y}\right)=D\left(\frac{\partial^{2} f}{\partial x^{2}}+\frac{\partial^{2} f}{\partial y^{2}}\right)$ 


\subsection{Solution of transport equation for point sources}

It is possible to produce the solution of the transport equation by writing it in terms of a new curvilinear coordinate system $(\phi, \psi)$ and, only then, solve it. To perform this task, initially, it is necessary to redefine the first and second order partial derivatives of the function $f(x, y)$ in terms of the velocity potential $\phi(x, y)$ and the stream function $\psi(x, y)$. By using the chain rule (Equations 6 and 7):

$$
\begin{aligned}
& \frac{\partial f}{\partial x}=\frac{\partial f}{\partial \phi} \frac{\partial \phi}{\partial x}+\frac{\partial f}{\partial \psi} \frac{\partial \psi}{\partial x} \\
& \frac{\partial f}{\partial y}=\frac{\partial f}{\partial \phi} \frac{\partial \phi}{\partial y}+\frac{\partial f}{\partial \psi} \frac{\partial \psi}{\partial y}
\end{aligned}
$$

And the identities and conditions of Cauchy-Riemann Equation 8:

$$
u=\frac{\partial \phi}{\partial x}=\frac{\partial \psi}{\partial y}, v=\frac{\partial \phi}{\partial y}=-\frac{\partial \psi}{\partial x}
$$

Writing the write the second-order derivative, regrouping the terms and making the necessary simplifications, the Laplacian of $f(x, y)$ is yielded in terms of the new coordinates $\phi$ and $\psi$ Equation 9:

$$
\begin{aligned}
& \nabla^{2} f(x, y)=\left(u^{2}+v^{2}\right)\left(\frac{\partial^{2} f}{\partial \phi^{2}}+\frac{\partial^{2} f}{\partial \psi^{2}}\right)+\frac{\partial f}{\partial \phi}\left(\left(u \frac{\partial u}{\partial \phi}-v \frac{\partial u}{\partial \psi}\right)+\left(v \frac{\partial v}{\partial \phi}+u \frac{\partial v}{\partial \psi}\right)\right)+\frac{\partial f}{\partial \psi}\left(\left(v \frac{\partial u}{\partial \phi}+u \frac{\partial u}{\partial \psi}\right)-\right. \\
& \left.\left(u \frac{\partial v}{\partial \phi}-v \frac{\partial v}{\partial \psi}\right)\right)
\end{aligned}
$$

The partial derivatives of the velocity field components $u$ and $v$ can be defined with the help of the chain rule, thus Equations 10 and 11:

$$
\begin{aligned}
& \frac{\partial u}{\partial x}=u \frac{\partial u}{\partial \phi}-v \frac{\partial u}{\partial \psi} \text { and } \frac{\partial u}{\partial y}=v \frac{\partial u}{\partial \phi}+u \frac{\partial u}{\partial \psi} \\
& \frac{\partial v}{\partial x}=u \frac{\partial v}{\partial \phi}-v \frac{\partial v}{\partial \psi} \text { and } \frac{\partial v}{\partial y}=v \frac{\partial v}{\partial \phi}+u \frac{\partial v}{\partial \psi}
\end{aligned}
$$

Once the relations Equation 10 and Equation 11 had replaced into Equation 9, the divergent and rotational of the velocity field will be cancelled, since incompressible and irrotational flows are being considered. This allows us to rewrite the diffusion terms of the target Equation 12 as:

$$
\nabla^{2} f(x, y)=\left(u^{2}+v^{2}\right)\left(\frac{\partial^{2} f}{\partial \phi^{2}}+\frac{\partial^{2} f}{\partial \psi^{2}}\right)
$$

In order to complete the procedure, it is also necessary to rewrite the advection terms of Equation 5 as a function of the new coordinates Equation 13:

$u \frac{\partial f}{\partial x}+v \frac{\partial f}{\partial y}=u\left(u \frac{\partial f}{\partial \phi}-v \frac{\partial f}{\partial \psi}\right)+v\left(v \frac{\partial f}{\partial \phi}+u \frac{\partial f}{\partial \psi}\right)=\left(u^{2}+v^{2}\right) \frac{\partial f}{\partial \phi}+(u v-v u) \frac{\partial f}{\partial \psi}$

Finally, the advection-diffusion equation for the steady state can be explained as a function of the new coordinate system. Equating the two sides in Equation 12 and Equation 13 and dividing by $\left(u^{2}+v^{2}\right)$, Equation 5 is thus rewritten as a function of curvilinear coordinates Equation 14:

\section{IPABH}


$\frac{\partial f}{\partial \phi}=D\left(\frac{\partial^{2} f}{\partial \phi^{2}}+\frac{\partial^{2} f}{\partial \psi^{2}}\right)$

The Equation 14, that describes the bi-dimensional model, can be solved by using Bäcklund (Polyanin and Zaitzev, 2004) and Fourier transformations (Spiegel, 1976). However, in this study, due to the restricted number of experimental data, we will consider the onedimensional problem.

\subsection{One-dimensional Model}

In the case of narrow or slow-flow rivers, as soon as the concentration distribution reaches the steady state the cross profile will be homogenized. Therefore, the diffusion term in this direction, $\left(\frac{\partial^{2} f}{\partial \psi^{2}}\right)$, can be neglected and the model will become one-dimensional, described through the ordinary differential Equation 15:

$\frac{d f}{d \phi}=D \frac{d^{2} f}{d \phi^{2}}$

Solving Equation 16 by the method of separation of variables and a second integration, the result is:

$f(\phi)=b_{0}+c_{o} e^{\frac{\phi}{D}}$

In this solution $b_{0}$ represents a constant buffer, namely, the minimum value of concentration that the substance of interest will reach, which can be considered null for nonconservative pollutants, since for these the concentration $C$ will fall to zero when $\phi \rightarrow-\infty$ in the absence of new sources. The constant $c_{0}$ represents the initial concentration of the contaminant at the point of discharge.

Reacting the solution obtained by Equation 17 to the solution of the kinetic equation given by Equation 4, we obtain:

$C=c_{0} e^{\left(\frac{\phi}{D}-k t\right)}$

Expression Equation 17 results in the concentration of the pollutant downstream from the point source given that the initial concentration of the pollutant and its velocity profile in the stretch are known.

\section{RESULTS AND DISCUSSION}

\subsection{Experimental data}

In order to validate the proposed solution, experimental data were used (Nascimento and Naime, 2009). The data were collected at the source, main body and mouth of the Pampa Creek, an affluent of the Sinos River, shown in Figure 1. The Sinos River supplies approximately 97\% of the urban population of the city of Novo Hamburgo in Rio Grande do Sul, Brazil (COMUSA, 2015). This city has an estimated population of 249,113 inhabitants (IBGE, 2017). Pampa Creek receives a domestic load from a region with approximately $40 \%$ of the total population of the city (Novo Hamburgo, 2017). Their effluents are discharged in the stream without any treatment, subsequently flowing into the Sinos River for about $1.5 \mathrm{~km}$ to the water collection point for treatment and subsequent public distribution for the city.

Point P1, located at the source of the Pampa Creek, has been taken as the starting point of the particles. Point P2, located midstream the course of Pampa is $3919 \mathrm{~m}$ away from P1, as well as P3, the mouth of the creek, which is located at $7669 \mathrm{~m}$ away from P1. Point P4, on the Sinos 
River, located next to the raw water pumping station of the water treatment plant is $1668 \mathrm{~m}$ downstream of P3.

Although the model described here has the ability to change the geometry under study, once the coordinate system has been modified, we intend to validate the results based on the one-dimensional approach given by Equation 17. For validation of the two-dimensional solution, Equation 14, it is necessary to obtain a more robust amount of data, such as pollutant concentration and velocity in more than one line along the water body.
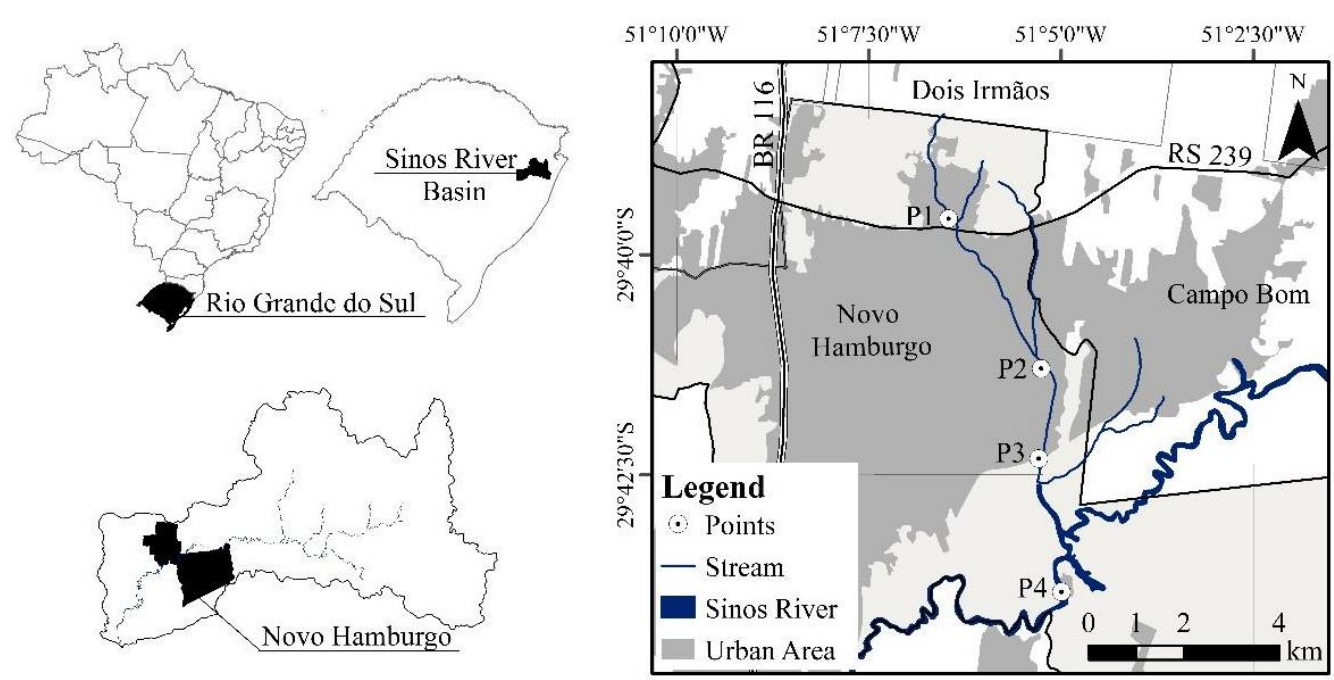

Figure 1. Pampa creek's location and data collection points.

The next figures show that the expression found as a problem solution (Equation 17) is experimental data adherent. The mean values for the thermotolerant coliforms measured from May 2006 to August 2006, and from January 2007 to March 2007, are presented, respectively, in Figures 2 and 3. We choose these periods because they had a similar precipitation profile. The samples were collected at the source of the Pampa Creek (P1), midstream along the course (P2), at the mouth of the brook (P3) and at the raw water collection point for water treatment in the Sinos River (P4), on eight different dates, at the four points of interest. The mean values show that the profile of coliform concentration from the data collected experimentally presents exponential decay, as suggested by the solution.

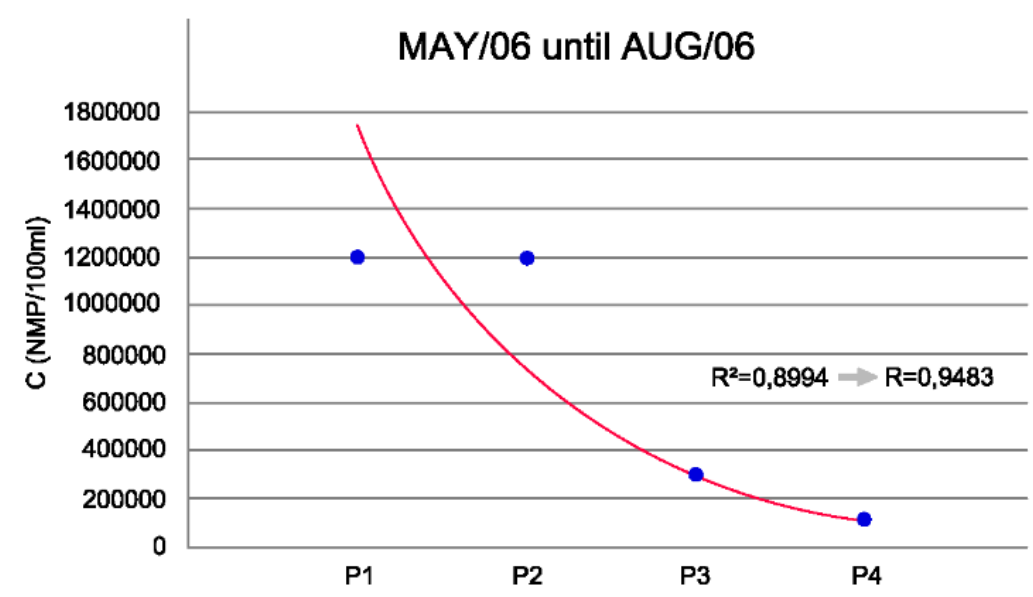

Figure 2. Average coliform concentration profile, from May to August 2006 at the 4 sampling points.

\section{IPABH}




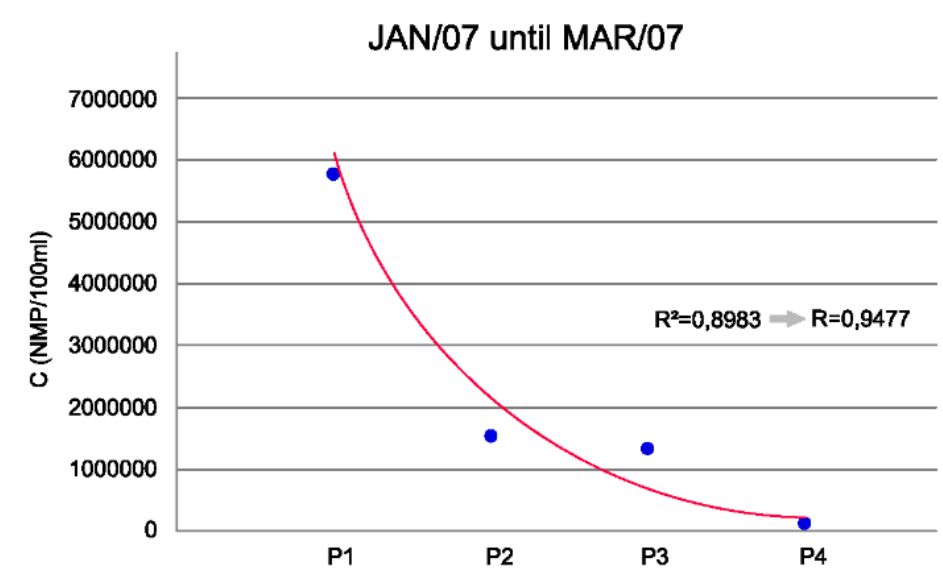

Figure 3. Average coliform concentration profile, from January to March 2007 at the 4 sampling points.

\subsection{Velocity Potentials}

The hydraulic variables are directly related to the watercourse flow. Thus, during rainy periods, and more frequently throughout autumn and winter, in this region of the country the flow velocity increases, as well as the level of the watercourse. Consequently, the depth and width of the water resource, along with the drainage area, increase.

The velocities at the four points selected for this study were obtained with the Flo-Mate ${ }^{\mathrm{TM}}$ portable speed meter Model 2000. Monthly measurements were performed at each of the points and are described in Tables 1,2 and 3. The mean velocity was used in each point and period of interest.

At the raw water collection point by the Municipal Company of Sanitation of Novo Hamburgo (COMUSA), P4, the mean velocity of the watercourse was used for the spring/summer period, which was measured at $0.37 \mathrm{~m} / \mathrm{s}$, and for the fall $/$ winter period, $0.69 \mathrm{~m} / \mathrm{s}$.

The $\phi(x)$ coordinate values were calculated at each point and date considering the mean value of flow velocity, $\underline{u}$, by the definition of the velocity potential (Equation 18):

$\phi(x)_{i}=\alpha \int_{0}^{-X_{i}} \bar{u} d x$

In Equation 18, $\alpha=10^{-4}$ represents a dimensionless correction value at the order of magnitude of the velocity to contemplate the effect that the stirring of the liquid mass exerts on the velocity measurement float, since it moves in all directions in very short intervals of time. This effect causes considerable amplifications on the diffusion coefficient as it promotes an essentially isotropic mixture when the shells formed on the surface of the water rise and fall alternately. Thus, it is not necessary to calculate the effective distance traveled over time accumulating the projections of the velocity vector on the main direction of the flow. The diffusion coefficient for the stagnant water (Brownian motion), for which the order of magnitude is 0.000001 (Bird et al., 2002), is then divided by the diffusion coefficient estimated by means of an oscillatory model derived from Navier-Stokes equations (model Korteweg-de Vries), the value of which is approximately 0.01 (Garcia et al., 2009). Thus, this quotient is on the order of $10^{-4}$. Note that this quotient equals the product between the instantaneous velocity and half of the mean free course.

Table 1. Measured velocity and velocity potentials at P1.

\begin{tabular}{lcccccccc}
\hline Period & May/06 & Jul/06 & Aug/06 & Oct/06 & Nov/06 & Jan/07 & Mar/07 & May/07 \\
\hline$\underline{u}(\mathrm{~m} / \mathrm{s})$ & 0.081 & 0.10 & 0.175 & 0.149 & 0.134 & 0.062 & 0.154 & 0.12 \\
$\phi(x)\left(\mathrm{m}^{2} / \mathrm{s}\right)$ & 0 & 0 & 0 & 0 & 0 & 0 & 0 & 0 \\
\hline
\end{tabular}


Table 2. Measured velocity and velocity potentials at $\mathrm{P} 2$.

\begin{tabular}{ccccccccc}
\hline Period & May/06 & Jul/06 & Aug/06 & Oct/06 & Nov/06 & Jan/07 & Mar/07 & May/07 \\
\hline$\underline{u}(\mathrm{~m} / \mathrm{s})$ & 0.23 & 0.102 & 0.376 & 0.326 & 0.392 & 0.367 & 0.394 & 0.39 \\
$\phi(x)\left(\mathrm{m}^{2} / \mathrm{s}\right)$ & -0.0966 & -0.03997 & -0.1435 & -0.1279 & -0.15391 & -0.14393 & -0.15441 & -0.15284 \\
\hline
\end{tabular}

Table 3. Measured velocity and velocity potentials at P3.

\begin{tabular}{ccccccccc}
\hline Period & May/06 & Jul/06 & Aug/06 & Oct/06 & Nov/06 & Jan/07 & Mar/07 & May/07 \\
\hline$\underline{u}(\mathrm{~m} / \mathrm{s})$ & 0.03 & 0.456 & 0.28 & 0.4518 & 0.063 & 0.221 & 0.242 & 0.18 \\
$\phi(x)\left(\mathrm{m}^{2} / \mathrm{s}\right)$ & -0.02301 & -0.34971 & -0.21473 & -0.3465 & -0.04875 & -0.16948 & -0.18559 & -0.13804 \\
\hline
\end{tabular}

\subsection{Coefficient of diffusion}

In the absence of any other characteristic that might make the probability of a molecule to migrate from one point to another be different for each direction of propagation of the pollutant, it is safe to assume that the diffusion coefficient is a constant value. Thus, the coefficient of diffusion by surface oscillation in microscale, $D$, was given by the quotient between the mean free courses and double the period between successive molecular collisions, in which $D=0.25 \mathrm{~m}^{2} / \mathrm{s}$ (Garcia et al., 2009).

\subsection{Coefficient of velocity}

The coefficient of velocity, $k$, presented in the model referring to the kinetics of bacterial and chemical pollutants decay, is indirectly dependent on the position and on the time variable. This dependency is due to the velocity constant being influenced by factors that can vary both in space and time, such as temperature, turbulence and wind incidence, which cause oscillations on the surface of the water body, in addition to the pollutant concentration itself.

For the determination of , the data for the calculation of another coefficient, T90, was used. This coefficient was obtained through laboratory assays and measures the time required to reduce the level of bacteria present in water by $90 \%$, i.e., to reduce the concentration to $10 \%$ of the original value at the point of emission. In the experiment (Lersch et al., 2013), this reduction occurred in $48 \mathrm{~h}$, which, based on the solution of the first order differential equation that describes the degradation kinetics, allowed us to estimate that the rate constant in $k=-0.0479$.

\subsection{Time}

The time has been calculated based on the distance that the particle traveled in each section and the mean velocity obtained experimentally. For each section, on each different date, the mean travel time was calculated. Given the ease of calculation by the reader and the great amount of information, no further explanations on this specific topic will be given, since there are eight different dates and four different points of the course evaluated.

\subsection{Simulations}

By using all the described data, it was possible to simulate the dispersion of thermotolerant coliforms based on the hypothesis that they are discharged at a specific location in the Pampa Stream and dispersed along its course.

The results of the simulations are presented on the different dates in which the samples were collected. Point P1 was taken as a source of pollutant discharge near the source of the stream and the amount of coliforms remaining at point P2 (midstream) was then simulated. Figure 4 presents the results obtained in the simulations and the measured values distributed in a scatter plot. In this graph, the complete agreement of the results with the experimental data is not shown, since this area is a highly urbanized zone, so point P1 is certainly not the only source of load in this stretch. 


\section{P1-P2}

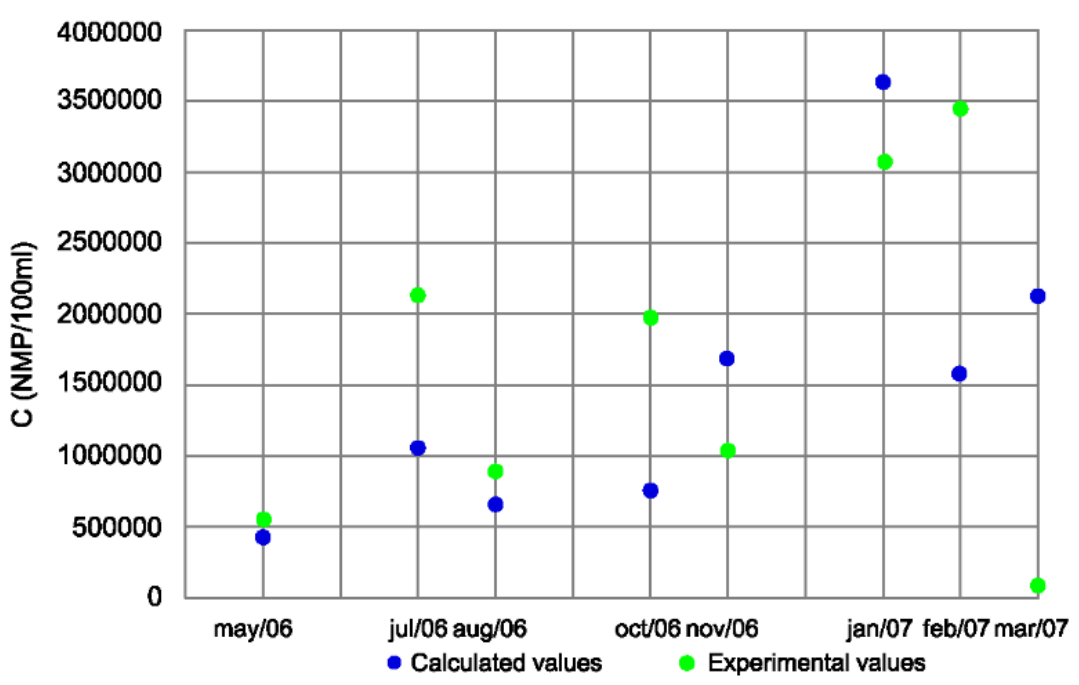

Figure 4. Experimental and simulated data. Discharge influence of $\mathrm{P} 1$ in $\mathrm{P} 2$.

Considering P2 as a point source of discharge, the amount of thermotolerant coliforms remaining at point $\mathrm{P} 3$, that is, at the mouth of the stream, was simulated. This result was presented in Figure 5, which shows a better agreement of the data obtained through the simulation and the values measured experimentally, due to the order of magnitude of the parameter involved.

\section{P2-P3}

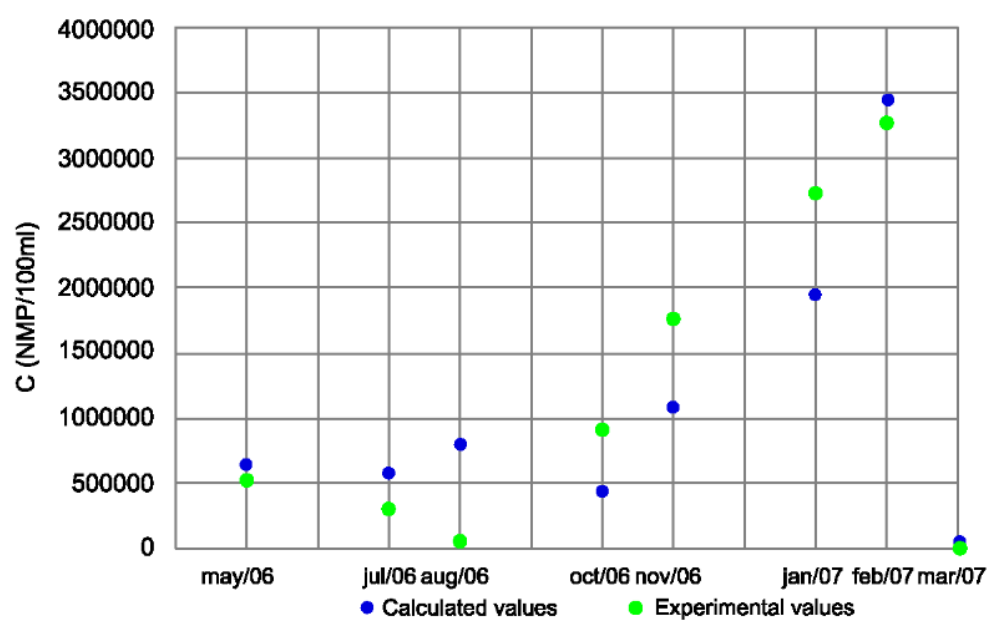

Figure 5. Experimental and simulated data. Discharge influence of $\mathrm{P} 2$ in $\mathrm{P} 3$.

The stretch from the mouth of the Pampa Creek (P3) to the point of water collection for treatment in the Sinos River (P4) is not urbanized, so there is no discharge point in between these places. Thus, all coliforms arriving at $\mathrm{P} 3$ were considered as input data and the remaining value at $\mathrm{P} 4$ was simulated, as shown in Figure 6. However, although the results obtained in the simulations were expected to agree almost totally with experimental data, the expected results were not verified on three of the dates. This is due to the input of water from the Sinos River near the mouth of the Pampa Creek, which impacts the poor quality of the experimental data obtained and, consequently, on the simulations. Given all hypothesis constraints imposed to the model performed, the reality hasn't reflected, at all. 


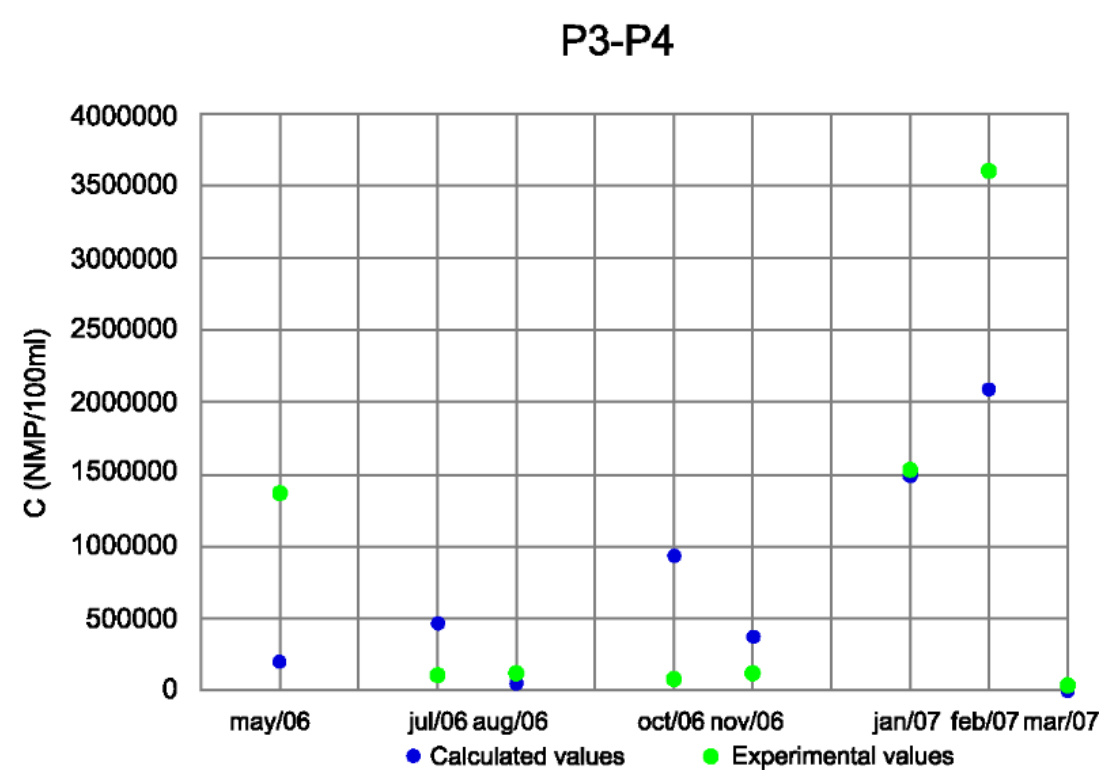

Figure 6. Experimental and simulated data. Discharge Influence ofP3 in $\mathrm{P} 4$.

The points P1, P2 and P3 are in the same watercourse, the Pampa Stream, whereas P4 is located in the course of the Sinos River, where the water flow and velocity change considerably. Thus, the difference between the calculated values and the respective experimental data is basically due to two causes of error: flow inversion and considerable fluctuations in the velocity field. Both factors are observed, frequently in periods of high flow rates, as was the case when experimental data were obtained. Since the hydrodynamic model employed considers the flow to be potential, implicitly the hypothesis of steady state is assumed. Therefore, any perturbation that produces transients in the velocity field had been neglected in the proposed model. Moreover, even the most refined hydrodynamic formulations based on the Navier-Stokes and Helmholtz equations (Bird et al., 2002; Mott, 2006) produce equally disparate results, since it is not possible to reproduce such fluctuations with fidelity, but only to estimate their amplitudes and frequencies in a relatively coarse manner. Haghiabi et al. (2018) examining models of artificial neural networks (ANN) and support vector machine (SVM), showed that all of them had some over-estimation properties. In short, the simplified hydrodynamic model is, in practice, as realistic as the finer formulations in fluid mechanics, even though they contemplate turbulence models.

In order to enable the analysis of the agreement of the results with the experimental data, both data were contrasted in dot cloud graphs, shown in Figure 7 and Figure 8. The bisecting line $y=x$, was plotted, in which the correlation coefficient was above $80 \%$, thus evidencing that the data are correlated.

\section{CONCLUSIONS}

The results obtained in this work are qualitatively consistent with the behavior of the phenomenon and relatively concordant from the quantitative point of view, proving the feasibility of the proposed solution. Even if some divergence is present, at least two main reasons could be listed. First, there may be regions where the cross stratification of the concentration profile is not negligible, whereas sampling may have been done in different flow lines, and such precision is not attainable experimentally. Second, the adoption of a constant mean velocity in each modeled portion could have caused a insignificant error in the calculation.

\section{IPABH}




\section{Relation P2 in P3}

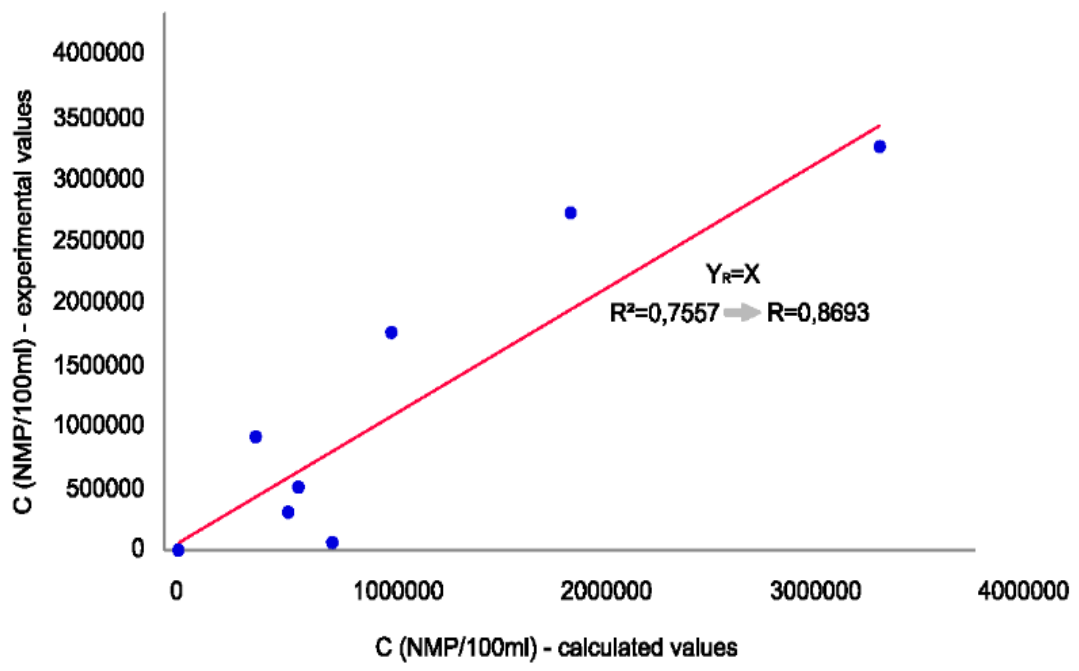

Figure 7. Distribution of the results around the bisector. Influence of $\mathrm{P} 2$ in $\mathrm{P} 3$.

\section{Relation P3 in P4}

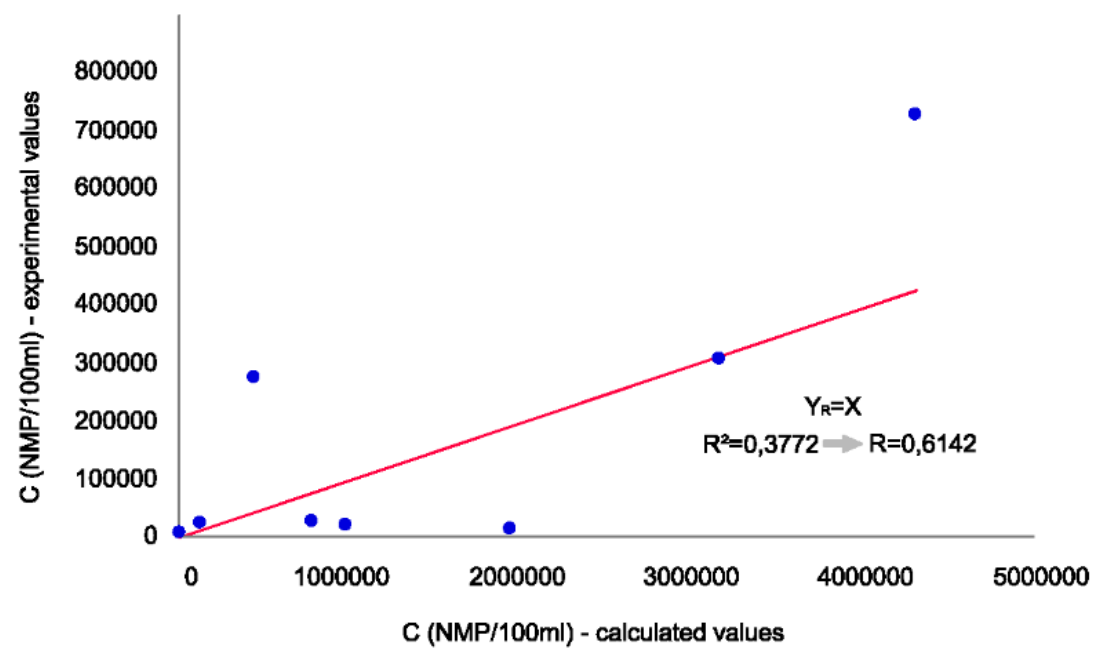

Figure 8. Distribution of the results around the bisector. Influence of $\mathrm{P} 3$ in $\mathrm{P} 4$.

However, despite the limitations of this preliminary analysis, the overall trend displayed by the complete set of numerical results agrees well with the experimental data given the proportion of order of magnitude involved. Considering that a deterministic model was proposed, while the studied phenomenon is strongly influenced by stochastic factors, a certain difference is not only expected but also perfectly understood due to the different characteristics of the data.

Once results had been obtained for the one-dimensional model, it seems reasonable to assume that the use of a two-dimensional model will refine the estimates. This assumption has been based on the possibility of reducing, for example, the potential error generated by not considering the different flow lines of each section. Thus, the authors intend to implement simulations of the two-dimensional model based on the solution of Equation 14 proposed in this study as soon as new experimental data of concentration and velocity are obtained in different flow lines along the water body. 


\section{REFERENCES}

BIRD, R. B.; STEWART, W. E.; LIGHTFOOT, E. N. Transport Phenomena. $2^{\text {nd }}$ ed. New York: John Wiley \& Sons, 2002.

COMPANHIA MUNICIPAL DE SANEAMENTO DE NOVO HAMBURGO/RS - COMUSA. Economias abastecidas pela Comusa aumentam 7\% nos últimos cinco anos. 2015. Available in: https://goo.gl/nD4tLN. Access: 21 Apr. 2017.

COTTA, R. M. Integral Transforms in Computational Heat and Fluid Flow. Boca Raton: CRC Press, 1993.

CRANK, J. The Mathematics of Diffusion. $2^{\text {nd }}$ ed. Bristol: Oxford University Press, 1975.

FERNANDEZ, L. C. Simulação da propagação de poluentes utilizando transformação de Backlund: modelo bidimensional. 2007. Dissertação (Mestrado em Engenharia Mecânica) - Universidade Federal do Rio Grande do Sul, Porto Alegre, 2007.

GARCIA, R. L.; ZABADAL, J.; RIBEIRO, V.; POFFAL, C. Definição do coeficiente de difusão para propagação de poluentes em águas rasas empregando um modelo baseado em soluções exatas para a equação de Korteweg-de Vries. Vetor, v. 19, n. 1, p. 15-27, 2009.

GOMES, S. H. R., SIQUEIRA, T. M.; GUEDES, H.; ANDREAZZA, R.; HUFFNER, A. N.; CORREAA, L. Modelagem sazonal da qualidade da água do Rio dos Sinos/RS utilizando o modelo QUAL-UFMG. Engenharia Sanitária e Ambiental, v. 23, p. 275-285, 2018.

GUERRERO, J. S.; PIMENTEL, L.; SKAGGS, T.; GENUCHTEN, M. Analytical solution of the advection-diffusion transport equation using a change-of-variable and integral transform technique. International Journal of Heat and Mass Transfer, v. 52, p. 3297 3304, 2009.

HAGHIABI, A. H. Prediction of longitudinal dispersion coefficient using multivariate adaptive regression splines. Journal of Earth System Science, v. 125, n. 5, p. 985-995, 2016.

HAGHIABI, A. H. Modeling River Mixing Mechanism Using Data Driven Model. Water $\begin{array}{lllllll}\text { Resources Management, } & \text { v. 31, n. 3, p. 811-824, }\end{array}$ http://dx.doi.org/10.1007/s11269-016-1475-7

HAGHIABI, A. H.; NASROLAHI, A. H.; PARSAIE, A. Water quality prediction using machine learning methods. Water Quality Research Journal, v. 53, n. 1, 2018. http://dx.doi.org/10.2166/wqrj.2018.025

IBGE. Infográficos: evolução populacional e pirâmide etária. 2017. Available in: https://goo.gl/zEUMpm. Access: 21 Apr. 2017.

KAMBE, T. Elementary Fluid Mechanics. Singapore: World Scientific Publishing, 2007.

JOBIM, G. S. Dispersão de poluentes: simulação numérica do Lago Guaíba. 2012. TCC (Graduação em Engenharia Civil) - Departamento de Engenharia Civil, UFRGS, Porto Alegre, 2012.

LERS.CH, E. C.; HOFFMANN, C. X.; ROSMAN, P. C. Relatório complementar de avaliação do impacto ambiental do projeto socioambiental ETE Serraria. Aplicação de Modelos Matemáticos Transientes. Porto Alegre: DMAE, 2013.

\section{IPABH}

Rev. Ambient. Água vol. 14 n. 2, e2298 - Taubaté 2019 
MIKHAILOV, M. D.; OZISIK, M. N. Unified Analysis and Solutions of Heat and Mass Diffusion. New York: John Wiley \& Sons, 1984.

MOTT, R. Applied Fluid Mechanics. $6^{\text {th }}$ ed. New Jersey: Prentice Hall, 2006.

NASCIMENTO, C.; NAIME, R. Monitoramento físico-químico das águas do Arroio Pampa em Novo Hamburgo/RS. Estudos Tecnológicos, v. 5, n. 2, p. 245-269, 2009.

NOVO HAMBURGO. Prefeitura Municipal. Estudos de concepção e projetos básicos de requalificação urbana e ambiental da sub-bacia do arroio Pampa - Novo Hamburgo - RS. 2017. Available in: https://goo.gl/VTLLUi. Access: 21 Nov. 2017.

PARSAIE, A.; HAGHIABI, A. H. Computational Modeling of Pollution Transmission in Rivers. Applied Water Science, v. 7, n. 3, p. 1213-1222, 2017. http://dx.doi.org/10.1007/s13201-015-0319-6

PARSAIE, A.; EMAMGHOLIZADEH, S.; AZAMATHULlA, H. M.; HAGHIABI, A. H. ANFIS-based PCA to predict the longitudinal dispersion coefficient in rivers. International Journal of Hydrology Science and Technology, v. 8, n. 4, p. 410-424, 2018. http://dx.doi.org/10.1504/IJHST.2018.095537

POLYANIN, A.; ZAITZEV, V. Handbook of Nonlinear Partial Differential Equations. Boca Raton: Chapman \& Hall/CRC, 2004.

QISHLAQI, A.; KORDIAN, S.; PARSAIE, A. Hydrochemical evaluation of river water quality - a case study. Applied Water Science, n. 7, p. 2337-2342, 2017. http://dx.doi.org/10.1007/s13201-016-0409-0

ROSMAN, P. C. C.; MASCARENHAS, F. C.; MIGUEZ, M.; CAMPOS, R.; EIGER, S. Um sistema computacional de hidrodinâmica ambiental. In: ABRH. Métodos Numéricos em Recursos Hídricos. vol. 5. Rio de Janeiro, 2009.

SANSKRITYAYN, A.; KUMAR, N. Analytical solution of advection-diffusion equation in heterogeneous infinite medium using Green's function method. Journal of Earth System Science, v. 125, p. 1713, 2016. https://doi.org/10.1007/s12040-016-0756-0

SPIEGEL, M. R. Fourier Analysis. New York: McGraw-Hill Publications, 1976.

ZABADAL, J. R.; RIBEIRO, V. Equações diferenciais para engenheiros: uma abordagem prática. Porto Alegre: UniRitter, 2012. 